\title{
Binding of Ribosomal Proteins to RNA Covalently Coupled
} to Agarose

\author{
Harry R. BURRELL and Jack HOROWITZ \\ Department of Biochemistry and Biophysics, Iowa State University, Ames, Iowa
}

(Received November 30, 1976)

\begin{abstract}
An affinity chromatographic procedure, using ribosomal or tRNA covalently coupled to agarose through an adipic acid dihydrazide spacer, has been developed to isolate and identify the Escherichia coli ribosomal proteins which specifically bind to these RNA molecules. Transfer RNA, 5-S, 16-S and 23-S ribosomal RNA were readily immobilized on agarose-dihydrazide; the maximum amount coupled decreasing with increasing molecular size. Specific binding of ribosomal proteins to RNA was observed in buffer containing $0.3 \mathrm{M} \mathrm{KCl}$ and $0.02 \mathrm{M} \mathrm{MgCl}_{2}$. Bound proteins were eluted with a high-salt, $2 \mathrm{M} \mathrm{KCl}$, buffer containing $0.005 \mathrm{M}$ EDTA. Two ribosomal proteins, identified as L18 and L25 by two-dimensional gel electrophoresis, bound tightly to E. coli 5-S RNA; small amounts of a third protein, L5, also were bound. These proteins did not bind to immobilized tRNA nor did 30-S ribosomal proteins bind to 5-S RNA. Denatured 5-S RNA bound less L18 and L25 than the native species. Several $30-\mathrm{S}$ and 50 -S ribosomal proteins bind to immobilized tRNA. The major 50-S subunit proteins tightly bound to tRNA were identified as L3, L4, L5, L7 and L8/L9. Smaller amounts of proteins L1, L2, L11, L16 and L21 were also observed. Proteins L2 and L16 were retarded by agarose-bound tRNA. Protein S3 was the major 30-S subunit protein bound to tRNA. Lesser quantities of proteins S6, S9, S13 and S18 also interacted with tRNA.
\end{abstract}

Studies of ribosomal protein - RNA interactions can give important information on the role of individual components in the structure and function of the ribosome. The discovery that the procaryotic ribosome can be self-assembled in vitro $[1,2]$ and the continuing elucidation of the highly intricate reaction sequence of protein biosynthesis, involving reversible associations of the ribosome with various exogenous molecules such as messenger RNA, transfer RNA, and nucleotides, suggest a priori that protein-protein and protein - nucleic acid interactions are essential in these complex macromolecular processes. Support for this supposition has come from several experimental approaches. Reconstitution experiments using purified ribosomal constituents have permitted a tentative identification of the ribosomal proteins that selectively bind to 5-S RNA [3-5], 16-S RNA [6-10], and 23-S RNA [11-14] and thus presumably are those vital to the structural integrity of the ribosome. Moreover, an impressive amount of data delineating functional sites on the ribosome has accumulated from recent investigations, utilizing such approaches

\footnotetext{
This is journal paper no. J-8606 of the Iowa Agriculture and Home Economics Experiment Station, Ames, Iowa. Project no. 1970.
}

as inactivation of ribosomal proteins or RNA by chemical modification [15-17], inhibition of a specific functional activity by reaction with antibodies directed against selected ribosomal proteins $[18,19]$ and affinity labeling of ribosomal components physically situated at a specific binding site $[20-26]$. A summary of some of this work is available [27]. From a correlation of these data one can infer that a surprisingly large number of ribosomal proteins from both subunits may be involved in interactions with extraribosomal RNA and protein factors during translation. The results, however, have not allowed an unambiguous identification of the elements comprising ribosomal active sites, perhaps owing to the indirect nature of these probes and to difficulties in interpretation caused by the high degree of cooperativity inherent in situ.

In an attempt to develop an alternative approach that would minimize such problems in the analysis of protein-RNA interactions, we have examined the applicability of affinity chromatography, a technique especially amenable to the isolation and identification of complexes formed between biological macromolecules. Results presented in an earlier communication [28] indicated that affinity chromatography using Escherichia coli 5-S RNA covalently coupled to 
agarose constituted a rapid and sensitive assay for the detection of selective interactions between ribosomal proteins and polynucleotides. We now report further characterizations of the RNA immobilization reaction and the usefulness of this procedure for the identification of those ribosomal proteins involved in 5-S RNA and transfer RNA binding.

\section{MATERIALS AND METHODS}

\section{Materials}

Cyanogen-bromide(CNBr)-activated Sepharose $4 \mathrm{~B}$ was purchased from Pharmacia Inc., AMP (sodium salt) was from Sigma Chemical Co. Acrylamide and $N, N^{\prime}$-methylenebisacrylamide (Eastman Kodak) were purified by recrystallization from chloroform and acetone, respectively, before use. Coomassie blue R250 and amido black were purchased from Canalco and pyronin $\mathrm{Y}$ was an Eastman Kodak product.

\section{Preparation of Ribosomes, Ribosomal Proteins and $R N A$}

Ribosomes were prepared from E. coli B cells purchased from Grain Processing Co. (Muscatine, Iowa). Cells were suspended in standard buffer (0.01 M Tris-HCl, pH 7.4, $0.01 \mathrm{M} \mathrm{MgCl}_{2}, 0.06 \mathrm{M}$ $\mathrm{NH}_{4} \mathrm{Cl}, 0.006 \mathrm{M}$ 2-mercaptoethanol) containing $2 \mu \mathrm{g}$ / $\mathrm{ml}$ deoxyribonuclease (ribonuclease-free) and disrupted by passage through a French pressure cell at $15000 \mathrm{lbs} / \mathrm{in}^{2}$ (103 MPa). Ribosomes were prepared essentially as described by Tisseres et al. [29] and were washed once in standard buffer and once in standard buffer containing $0.5 \mathrm{M} \mathrm{NH} \mathrm{N}_{4} \mathrm{Cl}$. The washed ribosomes were dialyzed against 41 standard buffer for $24 \mathrm{~h}$ at $4{ }^{\circ} \mathrm{C}$ and stored at $-75^{\circ} \mathrm{C}$ until used. Ribosomes were dissociated by dialysis against $0.01 \mathrm{M}$ potassium phosphate, $\mathrm{pH} 7.4,0.0001 \mathrm{M} \mathrm{MgCl}_{2}$, $0.01 \mathrm{M} 2$ 2-mercaptoethanol, and the subunits separated by centrifugation in a B-IV zonal rotor of the Beckman Model L-4 ultracentrifuge. The purity of each preparation was checked by sucrose density gradient centrifugation and there was generally less than $5 \%$ contamination of one subunit by the other. An equimolar mixture of the isolated subunits was fully active in $\left[{ }^{14} \mathrm{C}\right.$ polyphenylalanine synthesis when compared with the activity of undissociated 70-S ribosomes.

Ribosomal proteins were extracted from the ribosomal subunits by the urea/LiCl procedure of SpitnikElson [30]. The 50-S ribosomal proteins were further purified by chromatography on DEAE-cellulose as described by Nomura and Erdmann [31] to remove 5-S RNA, which was present in these preparations. The purified proteins were dialyzed against $1 \%$ acetic acid, lyophilized, and dissolved in $0.005 \mathrm{M}$ potassium phosphate, $\mathrm{pH} 7.4,0.3 \mathrm{M} \mathrm{KCl}, 0.02 \mathrm{M}$
$\mathrm{MgCl}_{2}, 0.006 \mathrm{M}$ 2-mercaptoethanol (binding buffer) at a concentration of $0.5-2.0 \mathrm{mg} / \mathrm{ml}$. At these concentrations not all the protein dissolved. Each of the protein constituents was found in solution. By twodimensional gel electrophoresis, however, less than normal quantities of proteins S1, L1, L3, L4, L5, and L21 were detected; the majority of these proteins were not soluble in binding buffer. Their solubility could be increased by first dissolving the ribosomal protein mixture in a small volume of $4 \mathrm{M}$ urea and then diluting this 100 -fold with binding buffer.

Ribosomal RNA was prepared from isolated ribosomal subunits and tRNA from the post-ribosomal supernatant by a phenol/sodium dodecyl sulfate method [32]. Individual RNA species were purified to homogeneity by gel filtration on Sephadex G-100 [33]. The purity of each component was confirmed by polyacrylamide gel electrophoresis [34] and staining with pyronin $Y$ [35]. In addition, representative samples from different tRNA preparations were tested for amino-acid-accepting activity in a system in vitro [36]. Levels of aminoacylation obtained with $\left[{ }^{14} \mathrm{C}\right]$ phenylalanine averaged approximately $1550 \mathrm{pmol} / \mathrm{mg}$ tRNA. RNA samples were dissolved in $0.01 \mathrm{M}$ Tris- $\mathrm{HCl}$ $\mathrm{pH} 7.4,0.01 \mathrm{M} \mathrm{MgCl}_{2}$ and stored at $-75^{\circ} \mathrm{C}$ until used.

\section{Preparation of Adipic-Acid-Dihydrazide-Sepharose}

Adipic acid dihydrazide was synthesized and attached to $\mathrm{CNBr}$-Sepharose $4 \mathrm{~B}$ according to the procedure of Lamed et al. [37]. The dihydrazideSepharose product was washed at room temperature with $0.2 \mathrm{M} \mathrm{NaCl}(1 \mathrm{l} / \mathrm{g}$ dry weight dihydrazideSepharose) and resuspended in $0.1 \mathrm{M}$ sodium acetate $\mathrm{pH}$ 5.0. The dihydrazide-agarose was stored at $4{ }^{\circ} \mathrm{C}$ and could be kept at least several months without significant loss of ligand-binding capacity.

\section{Periodate Oxidation of RNA and Coupling to Dihydrazide-Sepharose}

In the case of 5-S RNA and tRNA, oxidation with sodium periodate, at a final concentration of $0.0046 \mathrm{M}$, was carried out as described by Fahnstock and Nomura [38]. AMP, 16-S RNA, and 23-S RNA were oxidized by the method of Robberson and Davidson [39]. Excess periodate was removed by repeated precipitation of the RNA with two volumes of ethanol at $-20{ }^{\circ} \mathrm{C}$. Washed, oxidized RNA was dissolved in $0.1 \mathrm{M}$ sodium acetate $\mathrm{pH} 5.0$ at a concentration of $1-2 \mathrm{mg} / \mathrm{ml}$.

Coupling of oxidized RNA to the dihydrazideSepharose was accomplished by mixing the two preparations and agitating gently by end-over-end rotation in a test-tube at $4{ }^{\circ} \mathrm{C}$ for $24 \mathrm{~h}$ (except as noted in the kinetic binding experiments). The resulting 
RNA-Sepharose was washed repeatedly with $2.0 \mathrm{M}$ $\mathrm{KCl}$ to remove all non-covalently bound material. Washing was carried out at $4{ }^{\circ} \mathrm{C}$ by suspending the gel in the salt solution $(5-10 \mathrm{ml} / \mathrm{g}$ gel $)$, mixing for $20-30 \mathrm{~min}$, and then centrifuging the suspension in a clinical centrifuge. After the high-salt wash, the RNAagarose was washed and equilibrated with binding buffer.

The amount of RNA coupled to the agarosedihydrazide gel was determined indirectly by subtracting the amount of RNA recovered in the washes, estimated by measuring the absorbance at $260 \mathrm{~nm}$, from the amount originally added to the reaction mixture, using $A_{260 \mathrm{~mm}}^{0.1 \%}=24$. In several experiments a more direct determination was made by hydrolyzing the RNA on a portion of the gel with $1.0 \mathrm{M} \mathrm{KOH}$ at $25^{\circ} \mathrm{C}$ for $12 \mathrm{~h}$, and measuring the absorbance, at $260 \mathrm{~nm}$, of the supernatant remaining after removal of the gel by centrifugation. A correction was made for the approximately $40 \%$ hyperchromicity on hydrolysis of the RNA. The RNA-Sepharose was stored in binding buffer at $4{ }^{\circ} \mathrm{C}$. Little or no material absorbing at $260 \mathrm{~nm}$ was released during storage of the gel-bound RNA for several months.

\section{Chromatography of Ribosomal Proteins on RNA-Agarose}

RNA-agarose was poured to form a small column, $1.0 \times 4.5 \mathrm{~cm} / \mathrm{g}$ gel, and equilibrated at $4{ }^{\circ} \mathrm{C}$ with binding buffer. Ribosomal proteins, dissolved in binding buffer, were then passed over the column at a flow rate of $7-10 \mathrm{ml} / \mathrm{h}$. Unbound protein was removed by washing the column with several column volumes of binding buffer. Tightly bound proteins were then eluted with a linear gradient formed of equal volumes of binding buffer and of a high-salt/ EDTA dissociation buffer containing $0.005 \mathrm{M}$ potassium phosphate, pH 7.4, 2.0 M KCl, $0.005 \mathrm{M} \mathrm{Na}_{2}$ EDTA, $0.006 \mathrm{M}$ 2-mercaptoethanol. After use the RNA-agarose was re-equilibrated with binding buffer and stored at $4{ }^{\circ} \mathrm{C}$.

\section{Protein Concentration}

Protein concentrations were determined by the method of Lowry et al. [40], using bovine serum albumin as a standard. When mercaptoethanol was present in the protein sample, concentration was measured by the procedure described by Geiger and Bessman [41].

\section{Gel Electrophoresis of Ribosomal Proteins}

Disc gel electrophoresis at $\mathrm{pH} 4.5$ was carried out according to the procedure of Leboy et al. [42] in $10 \%$ acrylamide gels. Samples were treated with
Table 1. Binding of RNA to agarose-hydrazide

RNA or nucleotide samples either oxidized with periodate (see Methods) or not, as indicated, were mixed with dihydrazide-agarose in $0.1 \mathrm{M}$ sodium acetate buffer, $\mathrm{pH} 5.0$, at $4{ }^{\circ} \mathrm{C}$ for $24 \mathrm{~h}$. The resulting substituted agarose was washed repeatedly with $2 \mathrm{M} \mathrm{KCl}$ to remove all material not covalently attached. The amount of material bound was determined as described under Methods

\begin{tabular}{|c|c|c|c|c|c|}
\hline \multirow[t]{2}{*}{ Sample } & \multirow{2}{*}{$\begin{array}{l}\text { Amount } \\
\text { added }\end{array}$} & \multicolumn{4}{|c|}{ Amount bound } \\
\hline & & \multicolumn{2}{|c|}{ oxidized samples } & \multicolumn{2}{|c|}{$\begin{array}{l}\text { unoxidized } \\
\text { samples }\end{array}$} \\
\hline \multirow[b]{2}{*}{ Benzaldehyde } & \multirow{2}{*}{$\begin{array}{c}\mathrm{mg} / \mathrm{g} \text { gel } \\
2.7\end{array}$} & \multicolumn{4}{|c|}{$\mathrm{mg} / \mathrm{g} \operatorname{gel}(\mathrm{nmol} / \mathrm{g} \mathrm{gel})$} \\
\hline & & 0.5 & $(4700)$ & - & - \\
\hline AMP & 4.1 & 2.7 & $(7700)$ & 0.16 & $(460)$ \\
\hline tRNA & 7.3 & 5.5 & $(180)$ & 0.46 & $(1.5)$ \\
\hline tRNA & 15.9 & 13.1 & $(440)$ & - & - \\
\hline 5-S RNA & 7.3 & 6.1 & $(150)$ & 0.30 & $(7.0)$ \\
\hline 5-S RNA & 152 & 12.0 & $(300)$ & - & - \\
\hline 16-S RNA & 7.3 & 4.8 & $(8.7)$ & 1.4 & $(2.6)$ \\
\hline 23-S RNA & 7.3 & 5.3 & $(4.8)$ & 1.9 & $(1.7)$ \\
\hline
\end{tabular}

$0.06 \mathrm{M} 2$-mercaptoethanol at $\mathrm{pH} 8.1$ to prevent artifacts arising from sulfhydryl oxidation products [43]. Two-dimensional gel electrophoresis, for the identification of individual ribosomal proteins, was performed in the apparatus described by Kaltschmidt and Wittmann [44], modified in some experiments by the insertion of a plexiglass adapter to reduce the gel thickness and allow two samples to be analyzed on the same gel slab [28]; the gel and buffer systems developed by Howard and Traut [45] were used.

Staining of the gel slabs in Coomassie blue R250 was accomplished either in methanol/acetic acid for $3 \mathrm{~h} \mathrm{[45]} \mathrm{or} \mathrm{in} \mathrm{trichloroacetic} \mathrm{acid} \mathrm{for} 12 \mathrm{~h}$ [46]. In both procedures the gel slabs were destained by dialysis. Gel cylinders were stained with Coomassie blue R250 for $2 \mathrm{~h}$ and destained by washing with $5 \%$ methanol in $7 \%$ acetic acid.

\section{RESULTS AND DISCUSSION}

\section{Properties of RNA-Agarose gels}

In an earlier preliminary report [28] we described the coupling of periodate-oxidized 5-S RNA to adipicacid-dihydrazide-agarose in a one-step precedure that permits the immobilization of large amounts of RNA and avoids some of the drawbacks of the three-stage process described by Robberson and Davidson [39]. Here we examine the reaction in more detail and extend it to other RNA species.

The dihydrazide-agarose gel is capable of binding a wide range of oxidized RNA species of different molecular weights (Table 1); as much as $13 \mathrm{mg}$ tRNA or $12 \mathrm{mg} 5-\mathrm{S}$ RNA can be immobilized/g gel ( $3.5 \mathrm{ml}$ packed volume). It can be seen that the 
molar amount coupled decreases with the size of the bound ligand. Less than one-tenth the maximum binding capacity, as determined with benzaldehyde, is available for binding 5-S RNA or tRNA, and even less is available to bind $16-\mathrm{S}$ and $23-\mathrm{S}$ ribosomal RNA. Evidently smaller molecules have access to a larger number of dihydrazide groups and can, therefore, react more extensively with the matrix. The amount of 5-S RNA bound is not appreciably affected by treatment of the dihydrazide-agarose with $0.1 \mathrm{M}$ ethanolamine at $\mathrm{pH} 7.5$, before coupling RNA, to substitute any reactive groups remaining after the reaction of $\mathrm{CNBr}$-activated Sepharose with adipic acid dihydrazide (results not shown).

Appreciable binding of RNA to dihydrazideagarose occurs only with oxidized samples (Table 1); only small amounts of unoxidized AMP, tRNA, or 5-S RNA are retained on $2 \mathrm{M} \mathrm{KCl-washed} \mathrm{dihydra-}$ zide-agarose. Washing with high-salt buffers is necessary to remove non-covalently bound RNA effectively. This procedure could cause precipitation of highmolecular-weight RNA and may account for the relatively high levels of unoxidized 16-S RNA and 23-S RNA immobilized on the gels (Table 1).

Fig. 1 shows that the coupling reaction with RNA is rapid and is $90 \%$ complete within $4 \mathrm{~h}$. The rate of binding, as estimated from the time $\left(t_{1 / 2}\right)$ required to couple half the maximum amount of RNA, does not seem to depend on molecular weight. Values of $t_{1 / 2}$ ranged from 38-44 min for the RNA species examined. The binding of unoxidized RNA follows essentially the same time course as that of the oxidized molecules.

The coupling of 5-S RNA to agarose is quite stable when the gel is stored in binding buffer (Materials and Methods) at $4{ }^{\circ} \mathrm{C}$. In a typical case less than $5 \%$ of the $240 A_{260}$ units of RNA bound to Sepharose was released after 6 months.

\section{Affinity Chromatography}

of E. coli Ribosomal Proteins on 5-S-RNA-Agarose

As a test of the ability of RNA immobilized on Sepharose to bind ribosomal proteins specifically, we have examined the interaction of these proteins with 5-S-RNA-agarose. In a previous communication [28], we briefly described a batch procedure for studying this interaction. To increase the efficiency of the protein-RNA binding and to detect proteins that bind only weakly to the RNA, a column chromatographic procedure was developed. Chromatography of E. coli 50-S ribosomal proteins on a 5-S RNAagarose column gave the results shown in Fig. 2. A majority of the protein was not retained on the column in buffer containing $0.3 \mathrm{M} \mathrm{KCl}$. However, a small fraction of the protein bound rather tightly to the matrix and was eluted as a single peak by a highsalt/EDTA buffer (Fig.2). The bound protein re-

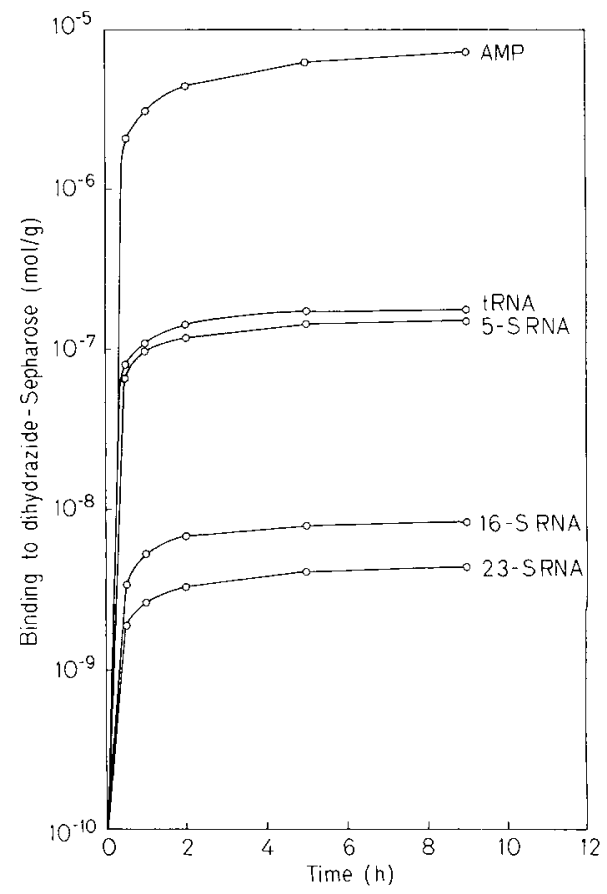

Fig. 1. Kinetics of RNA and mucleotide binding to dihydrazideSepharose. Periodate-oxidized nucleotide or RNA sample was mixed with dihydrazide-Sepharose in $0.1 \mathrm{M}$ sodium acetate buffer, $\mathrm{pH} 5.0$, at $4{ }^{\circ} \mathrm{C}$ for the indicated time. Non-covalently attached material was removed by washing with $2 \mathrm{M} \mathrm{KCl}$ and the amount remaining bound to the gel was determined as described under Methods

presented $6.5 \%$ of the total protein put on the column. This elution procedure removed all the bound protein. None was detected by gel electrophoresis after solubilization of the RNA-agarose gel by heating in $0.4 \mathrm{M} \mathrm{HCl}$ at $100{ }^{\circ} \mathrm{C}$ for $0.5 \mathrm{~h}$.

Disc gel electrophoresis of the protein fraction bound tightly to 5-S-RNA-agarose showed two major bands (Fig. 3 B). Several faint bands were visible near the top (anodic) portion of the gel and a diffuse, lightly stained band could be observed toward the bottom of the gel. The major protein components binding to 5-S RNA were identified as L18 and L25 by two-dimensional gel electrophoresis (results not shown) and positive identification was made by coelectrophoresis of a mixture of 5-S RNA-binding proteins with a small amount of total 50-S ribosomal proteins. The unknown proteins are then readily identifiable against the light background of total 50-S ribosomal proteins (Fig.4). Small amounts of L5 were also detected on these gels but were stained too faintly to be readily visible in photographs. As found earlier with the batch procedure [28], essentially all the L18 and L25 in the ribosomal protein mixture are retained on the 5-S RNA matrix. Only a small fraction of L5 is firmly bound, most of this protein is found among the proteins not bound to immobilized 5-S RNA. 


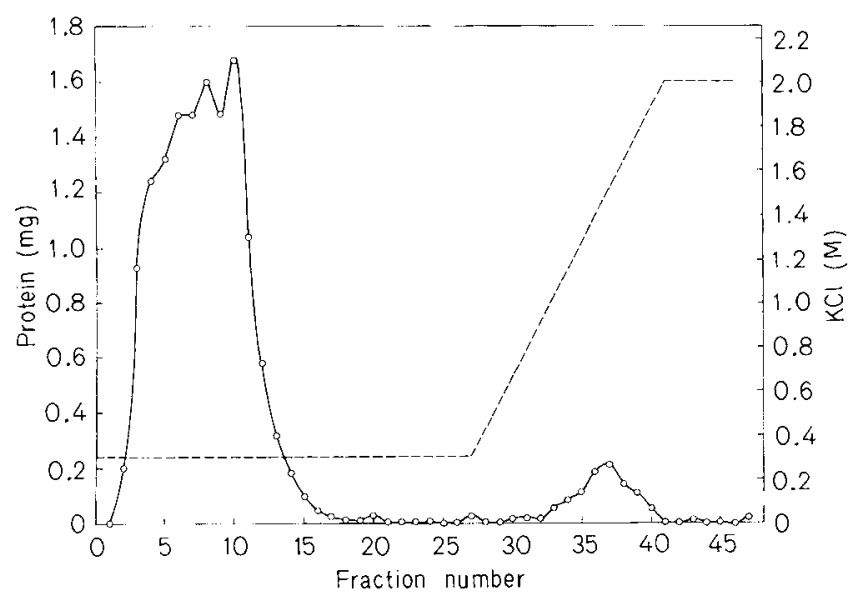

Fig. 2. Affinity chromatography of E. coli $50-S$ ribosomal proteins on $5-S-R N A$-agarose. $15 \mathrm{mg} 50-\mathrm{S}$ ribosomal proteins in $16 \mathrm{ml}$ binding buffer $(0.005 \mathrm{M}$ potassium phosphate, $\mathrm{pH} 7.4 ; 0.3 \mathrm{M} \mathrm{KCl}$; $0.02 \mathrm{M} \mathrm{MgCl}_{2} ; 0.006 \mathrm{M} 2$-mercaptoethanol) was chromatographed on a $1.0 \times 4.5-\mathrm{cm} 5-\mathrm{S}-\mathrm{RNA}$-agarose column, containing $11 \mathrm{mg}$ RNA; 2,0-ml fractions were collected. The column was washed with binding buffer to remove unbound proteins. Bound proteins were eluted with a linear gradient of $\mathrm{KCl}(0.3-2.0 \mathrm{M})$ and EDTA $(0-0.005 \mathrm{M}) .(-\cdots-) \mathrm{KCl}$ concentration

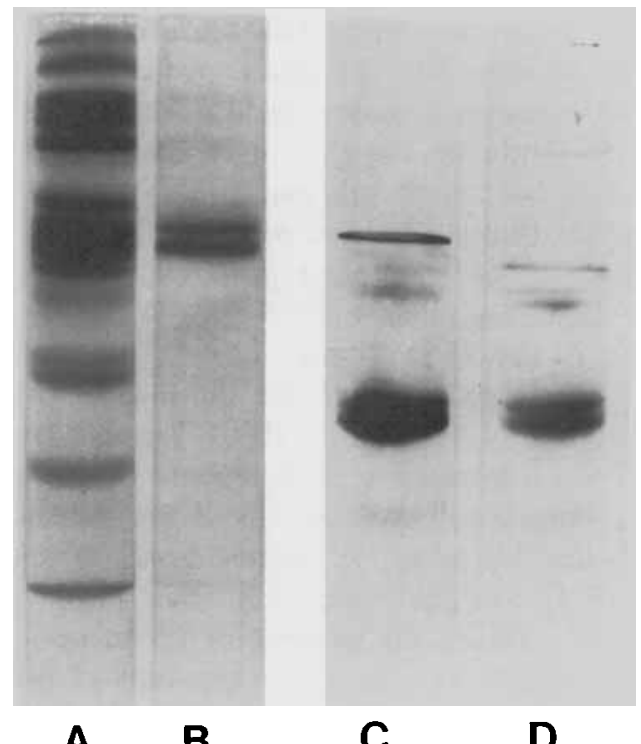

A

B

Fig. 3. Electrophoresis of 50-S ribosomal proteins bound to 5-S RNA coupled to agarose. (A) Total 50-S ribosomal proteins. (B) The 50-S ribosomal proteins bound to a 5-S-RNA-agarose column and eluted with high-salt/EDTA buffer (see Fig. 2). A batch procedure, described earlier [28], for examining the interaction of proteins with immobilized RNA was used in experiments (C) and (D). (C) The 50-S ribosomal proteins bound to native 5-S RNA (1.9 mg) coupled to agarose. (D) The $50-\mathrm{S}$ ribosomal proteins bound to denatured 5-S RNA (2.1 mg) coupled to agarose, 5-S RNA was denatured by heating at $60^{\circ} \mathrm{C}$ in magnesium-free buffer. Each gel contained all the protein recovered in the high-salt/EDTA wash

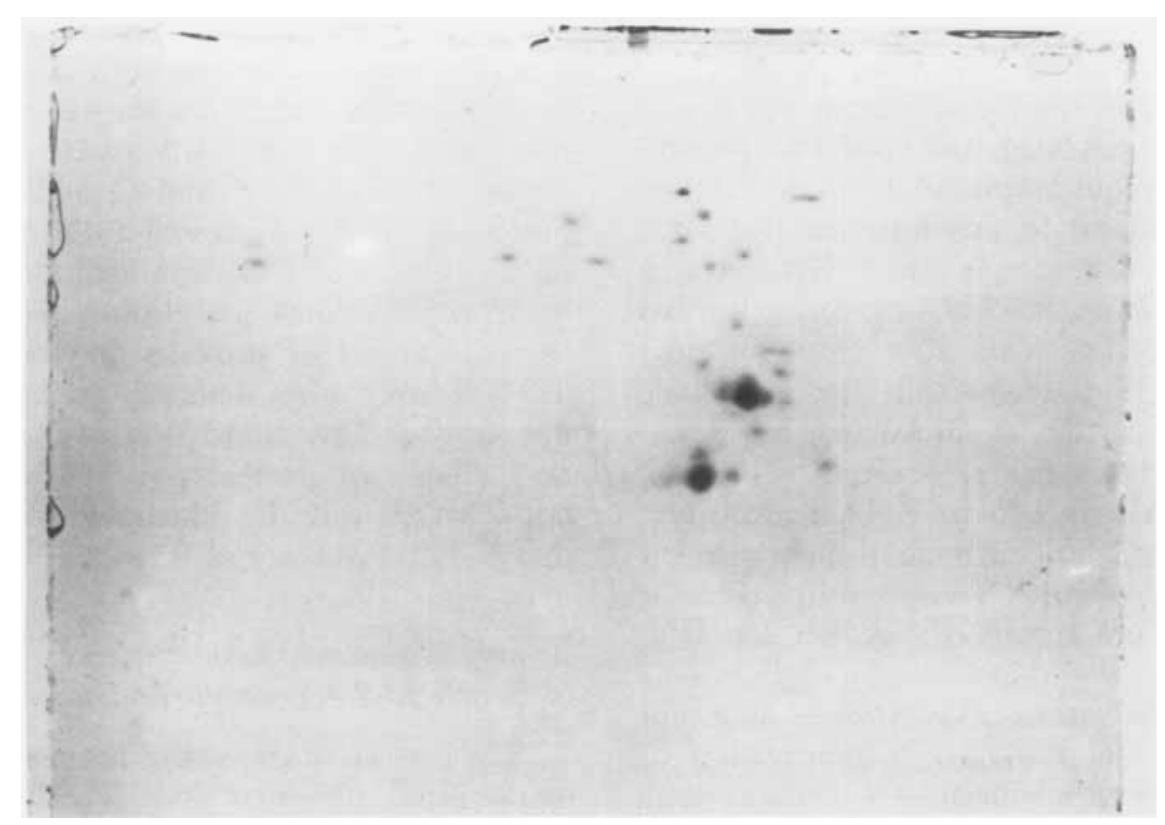

Fig. 4. Two-dimensional gel electrophoresis of the 50-S ribosomal proteins bound to 5-S-RNA-agarose. The 50-S ribosomal proteins bound to 5-S-RNA-agarose and eluted with high-salt/EDTA buffer (see Fig. 2) were mixed with a small amount, $25 \mu \mathrm{g}$, of total 50-S ribosomal subunit proteins and the mixture separated by polyacrylamide gel electrophoresis as described in Methods. The darkly staining spots represented the 5-S-RNA-binding proteins and were positively identified as L18 and L25 from their position relative to the other ribosomal proteins 
When buffer containing $2 \mathrm{M} \mathrm{KCl}$, but no EDTA, was used to elute the ribosomal proteins bound to 5-S RNA-agarose, a major fraction of the L25 was recovered. However, the elution of proteins L18 and L5 requires both high salt and EDTA, indicating a differential affinity of these proteins for 5-S RNA. Garrett et al. [47] noted a preferential release of protein $\mathrm{L} 25$, together with 5-S RNA, during the unfolding of the 50 -S subunit.

Our observation of specific binding of proteins L5, L18, and L25 to 5-S RNA immobilized on agarose is in agreement with reports of complexes between these proteins and 5-S RNA detected by nitrocellulose filtration [5], sucrose gradient centrifugation [3,5] and gel electrophoresis [3,4]. These workers also found the binding of L5 to be weaker than that of L18 or L25. Trace amounts of proteins L20 and L30 have also been found associated with 5-S RNA [3] and these may correspond to the faint bands seen on disc gel electrophoresis of the protein fraction bound to immobilized 5-S RNA (Fig.3).

\section{Specificity of Ribosomal Protein Binding} to 5-S-RNA-Agarose

To examine the requirements for ribosomal protein binding in greater detail, several parameters were examined. Total $70-\mathrm{S}$ ribosomal proteins could not substitute for $50-\mathrm{S}$ subunit proteins in the binding reaction with 5-S RNA; L5, L18, and L25 present in the 70-S ribosomal protein mixture did not bind to immobilized 5-S RNA under the conditions used, possibly because of stronger protein - protein interactions in solution.

No detectable 50-S ribosomal protein was bound to adipic-acid-dihydrazide-agarose itself, thus demonstrating a specific requirement for RNA and ruling out binding of proteins to unsubstituted hydrazide groups or to reactive groups on $\mathrm{CNBr}$-activated Sepharose. Furthermore, 5-S-RNA-agarose gels treated with $0.5 \mathrm{M}$ acetylaldehyde after immobilization of the RNA, to block remaining free hydrazide groups, behaved exactly as unreacted 5-S-RNAagarose in binding ribosomal proteins.

Binding of L18 and L25 to RNA-agarose was specific for 5-S RNA; little or none of these proteins were bound tightly when tRNA was substituted for 5-SRNA in the gel matrix (however, see later discussion).

The native conformation of the RNA is important for binding ribosomal proteins. A preparation of 5-S RNA, denatured by heating at $60^{\circ} \mathrm{C}$ in the absence of $\mathrm{Mg}^{2+}$ [48] and then oxidized and coupled to dihydrazide-agarose by the usual procedures, bound less of the proteins L18 and L25 than did an equal amount of native 5-S RNA (compare Fig. $3 \mathrm{C}$ and D). Measurement of the areas under the major peaks, after spectrophotometric scans of the stained gels at $550 \mathrm{~nm}$, indicated that approximately half as much protein bound to the denatured 5-S RNA sample as to the native sample. This does not necessarily imply that the ribosomal proteins bind to denatured 5-S RNA; Aubert et al. $[48,49]$ found that denatured 5-S RNA bound no ribosomal proteins. Our denatured 5-S RNA preparation was not fractionated and examination on Sephadex G-100 [48] before coupling to the dihydrazide-agarose showed that it contained about $20 \%$ native RNA. The ribosomal protein that bound to the denatured 5-S RNA preparation may be interacting with the residual native RNA or with RNA renatured after coupling to the dihydrazide-agarose gel. It is clear, however, that exposure of the RNA to denaturing conditions does reduce the binding of ribosomal proteins. In addition, initial experiments with immobilized rabbit reticulocyte 5-S RNA and yeast 5-S RNA have shown that E. coli 5-S-RNA-binding proteins do not bind to these RNAs, again emphasizing the importance of RNA structure in the interaction with proteins.

No 30-S ribosomal proteins bound tightly to 5-SRNA-agarose when chromatographed under the same conditions used with 50-S proteins (Fig. 5); there were no detectable proteins in the high-salt/EDTA wash (Fig.6, sample H). However, some 30-S ribosomal proteins seemed to show a weak affinity for the matrix and were eluted only slowly from the 5-S RNA gel by binding buffer. This resulted in a trailing effect not seen in the chromatographic pattern of 50-S ribosomal protein on 5-S-RNA-agarose (compare Fig. 2). Disc gel electrophoretic analyses of the ribosomal proteins present in various fractions, pooled as indicated in Fig. 5, are shown in Fig. 6. Proteins retarded by the 5-S RNA matrix were present in pooled fractions $\mathrm{E}, \mathrm{F}$ and $\mathrm{G}$ in Fig. 5 and 6 . The protein in fraction $F$, as well as the major constituent of fractions $E$ and $G$, was identified as protein $S 3$ by two-dimensional gel electrophoresis (results not shown). Traces of proteins S6, S9, S13, S18, and S19/S20 were also detected in fraction $\mathrm{E}$ (results not shown). This retardation of a small number of 30-S ribosomal proteins on 5-S-RNA-agarose was not observed with the dihydrazide-agarose gel alone, that is, in the absence of RNA.

\section{Affinity Chromatography \\ of E. coli 50-S Ribosomal Proteins on tRNA-Agarose}

The pattern of ribosomal protein interaction with immobilized tRNA is considerably more complex than that with 5-S RNA, both in the number of proteins bound and in the strength of the binding. In earlier experiments using the batch procedure little or no 50-S ribosomal protein was bound to tRNAagarose [28]. When 50-S ribosomal proteins were 


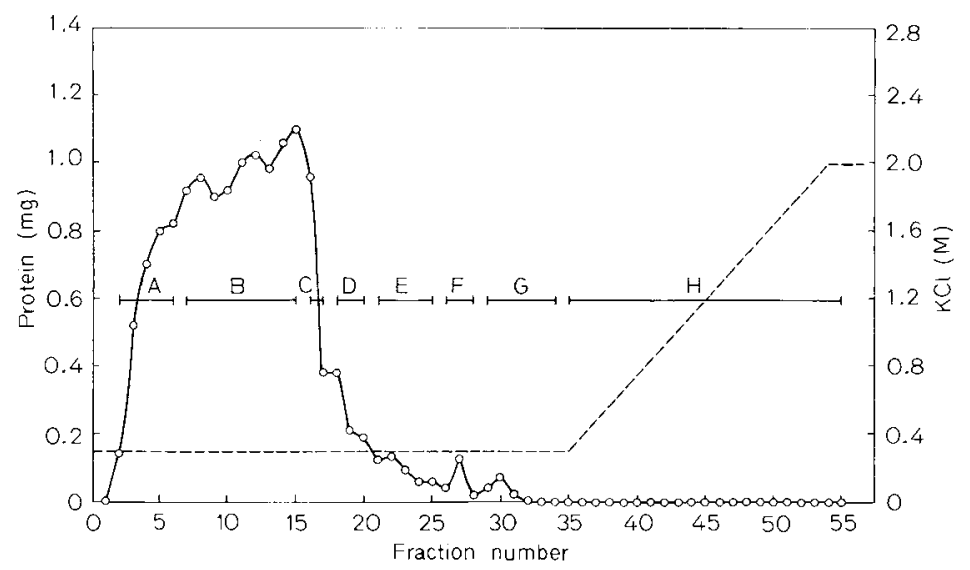

Fig. 5. Affinity chromatography of E. coli 30-S ribosomal proteins on 5-S-RNA-agarose. $16 \mathrm{mg} 30$-S ribosomal proteins in $28 \mathrm{ml}$ binding buffer was chromatographed, as in Fig. 2, on a 5-S-RNA-agarose column containing $10 \mathrm{mg}$ 5-S RNA; 2.0-ml fractions were collected. These were pooled, as indicated, for analysis by polyacrylamide gel electrophoresis (see Fig. 6). (----) $\mathrm{KCl}$ concentration

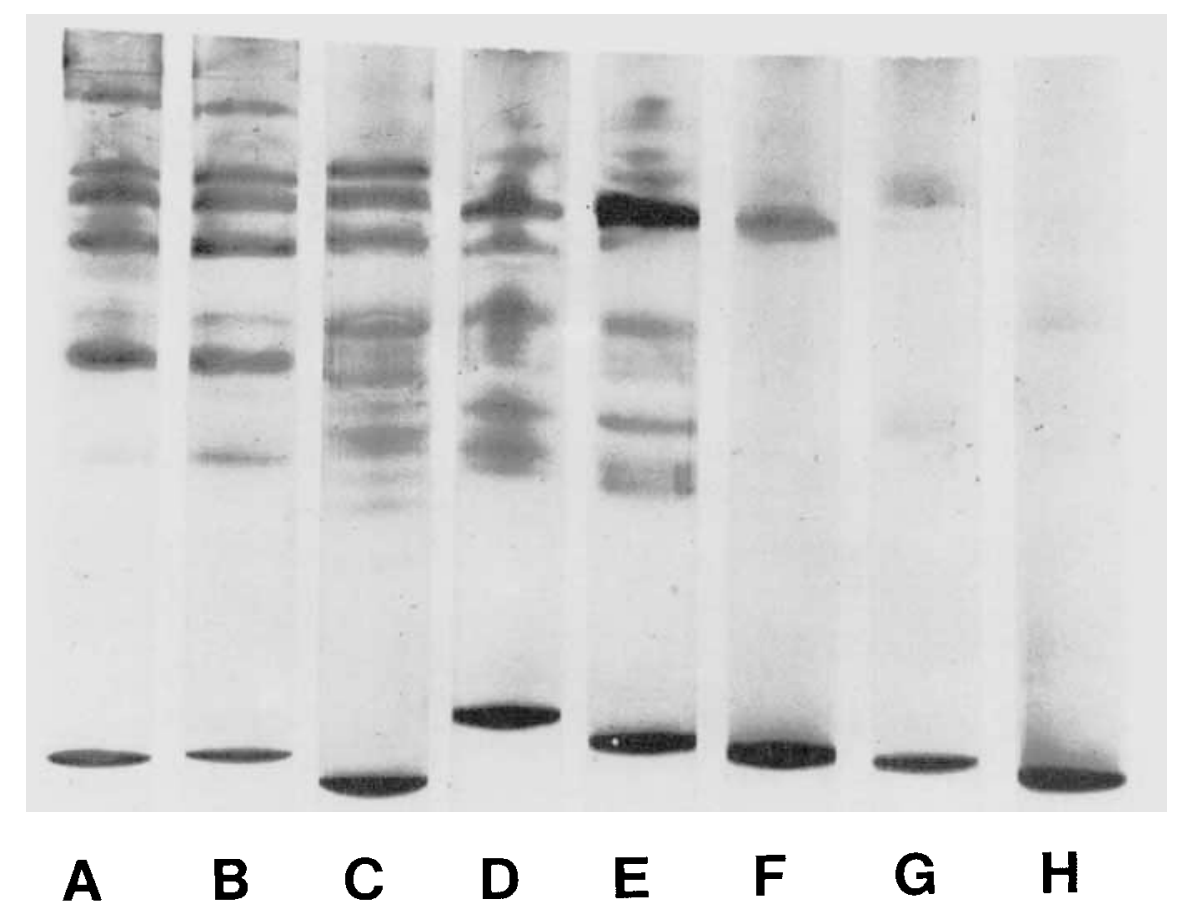

Fig. 6. Disc gel electrophoresis of the E. coli 30-S ribosomal proteins fractionated on a 5-S-RNA-agarose column. Protein fractions wcre pooled as indicated in Fig. 5. The darkly stained band at the bottom of each gel is an artifact of the staining procedure and does not represent a protein component

chromatographed on a tRNA-agarose column, however, significant amounts of protein were retained on the matrix and eluted with the high-salt/EDTA gradient (Fig. 7, fractions $\mathrm{H}$ and I). In addition, some proteins were retarded but not strongly bound by the tRNA gel; these were eluted from the column as a broad shoulder during the wash with binding buffer (Fig. 7, fractions E-G). Disc gel electrophoretic examination of the column fractions, pooled as indicated in Fig. 7, gave the results shown in Fig. 8. Two darkly stained protein bands and several lighter ones were present in the ribosomal protein fractions tightly bound to immobilized tRNA (samples $\mathrm{H}$ and I of Fig. 8). Neither of the major bands had the mobility of L18 or L25. Two-dimensional gel electrophoresis permitted identification of the major constituents as proteins L3, L4, L5, L7, and L8/L9 (Fig. 9A). Smaller amounts of proteins L1, L2, L11, L16, and L21 as well as traces of several others, difficult to identify, were also observed. Proteins L18 and L25, the two major 50-S ribosomal proteins found to bind directly to immobilized 5-S RNA, were either absent or present only in barely detectable quantities. Much more protein $\mathrm{L} 5$ bound to tRNA-agarose than to an 


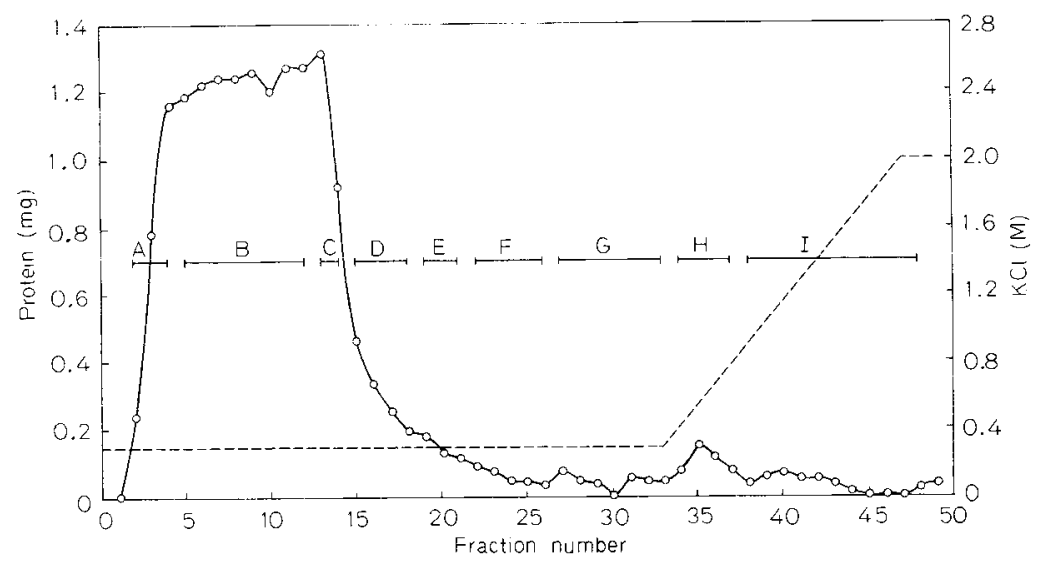

Fig. 7. Affinity chromatography of $\mathrm{F}$. coli $50-5$ ribosomal proteins on 1 RNA-agarose. $22 \mathrm{mg} 50$-S ribosomal proteins in $21 \mathrm{ml}$ binding buffer was chromatographed on a tR NA-agarose column containing $9.5 \mathrm{mg}$ tRNA; 2.0 -ml fractions were collected. These were pooled as indicated, for polyacrylamide gel electrophoretic analysis (see Fig. 8 and 9). (-..-) $\mathrm{KCl}$ concentration

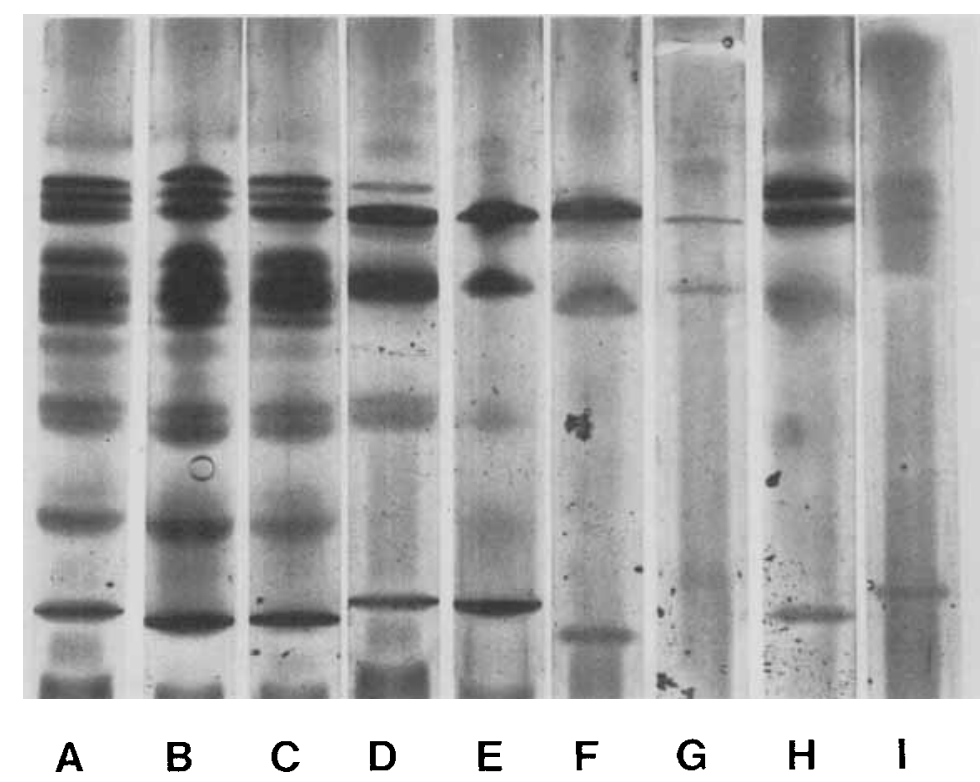

Fig. 8. Disc gel electrophoresis of E. coli 50-S ribosomal proteins chromatographed on $t R N A$-agarose. Protein fractions were pooled as indicated in Fig. 7. The darkly stained band at the bottom of each gel is an artifact of the staining procedure and does not represent a protein component

equivalent amount of immobilized 5-S RNA, as judged by the intensities of staining on the gel slabs.

The 50-S ribosomal proteins retarded by tRNAagarose, pooled fractions $\mathrm{E}, \mathrm{F}$, and $\mathrm{G}$ in Fig. 8, were identified by two-dimensional gel electrophoresis as L2 and L16 (Fig.9B), indicating that these two proteins interact weakly with immobilized tRNA.

In contrast to the tight affinity binding of proteins L18 and L25 to 5-S-RNA-agarose, each of the 50-S ribosomal proteins observed in the fractions binding to, or retarded by, tRNA-agarose was also observed among the proteins in the unbound portion. This may signify that a saturating amount of each of the bound 50-S ribosomal proteins had reacted with the affinity reactive center in the $t R N A$ matrix.

\section{Affinity Chromatography}

of E. coli 30-S Ribosomal Proteins on tRNA-Agarose

An extensive and complex pattern of interactions between 30-S ribosomal proteins and TRNA immobilized on Sepharose was observed. The result of one such affinity chromatography experiment is shown in Fig.10. As in experiments examining the interaction of 30-S ribosomal proteins with 5-S-RNAagarose (Fig. 5) and 50-S ribosomal proteins with tRNA-agarose (Fig. 7), a trailing effect was noted in the elution pattern, suggesting the occurrence of weak interactions with tRNA, as well as the stronger ones required for tight binding of proteins to the tRNA-agarose. Column fractions were pooled as 
A

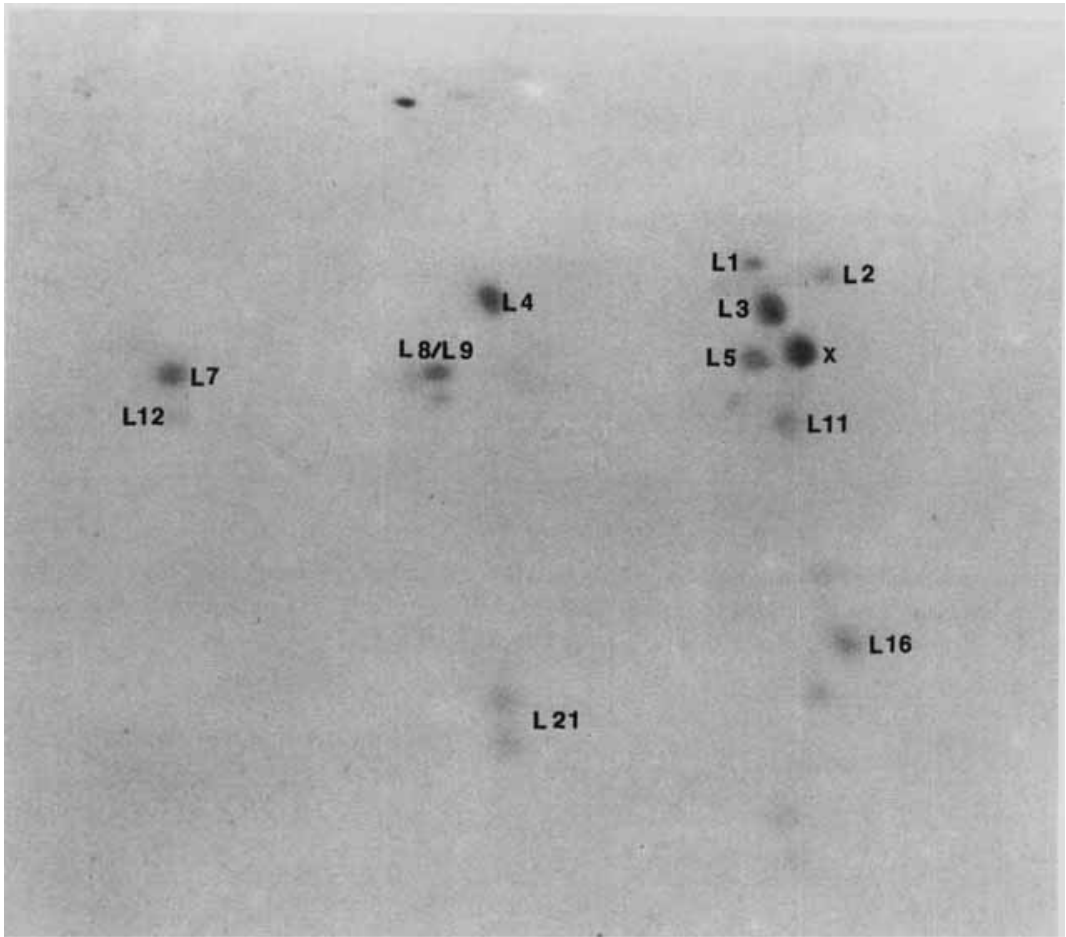

B

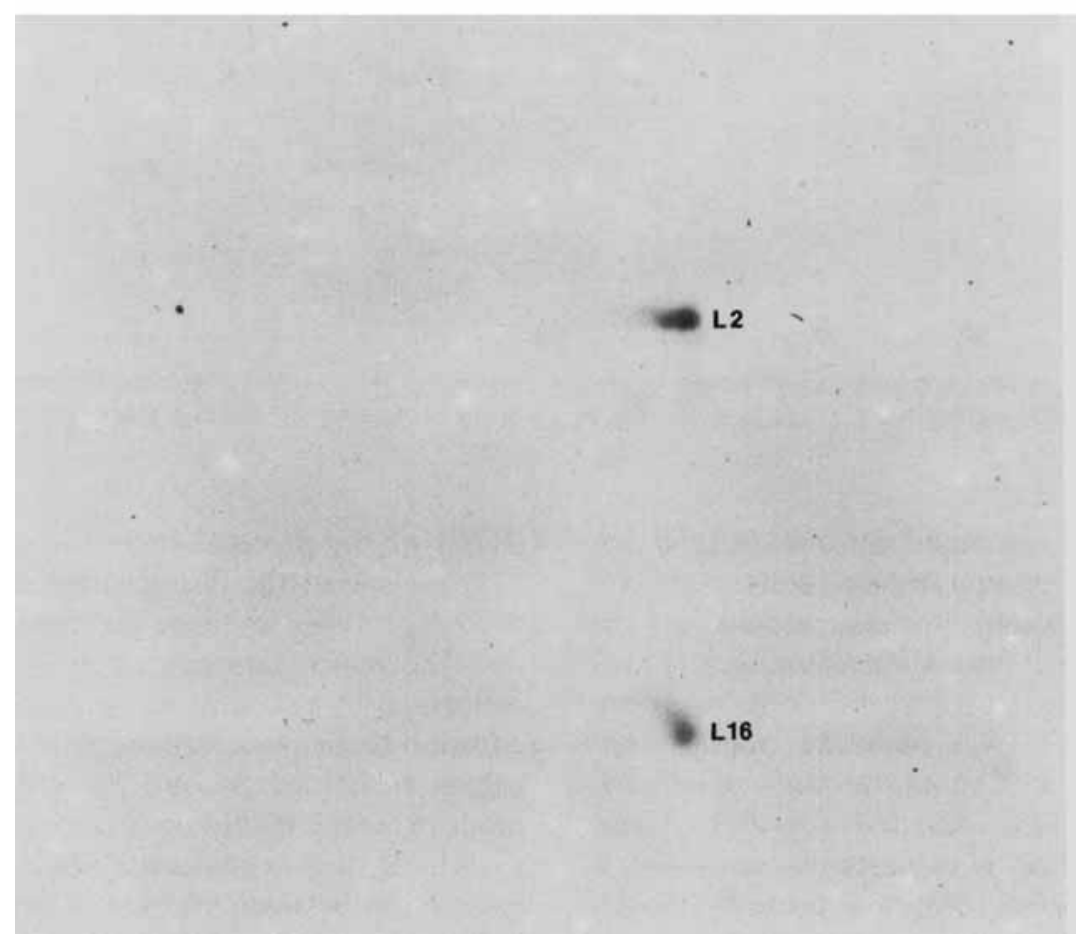

Fig.9. Two-dimensional gel electrophoresis of the E. coli 50-S ribosomal proteins bound to tRNA-agarose. Pooled ribosomal protein fractions (see Fig. 7 and 8) were electrophoresed on two-dimensional polyacrylamide gels as described in Methods. (A) Pooled fraction H (Fig. 7). The spot marked $\mathrm{X}$ did not correspond to any known ribosomal protein. Variable amounts of this constituent were observed in different experiments; it was not present in the 50 -S ribosomal protein preparation put on the tRNA-agarose column, nor was it observed in any other fraction. (B) Pooled fraction F (Fig. 7) 


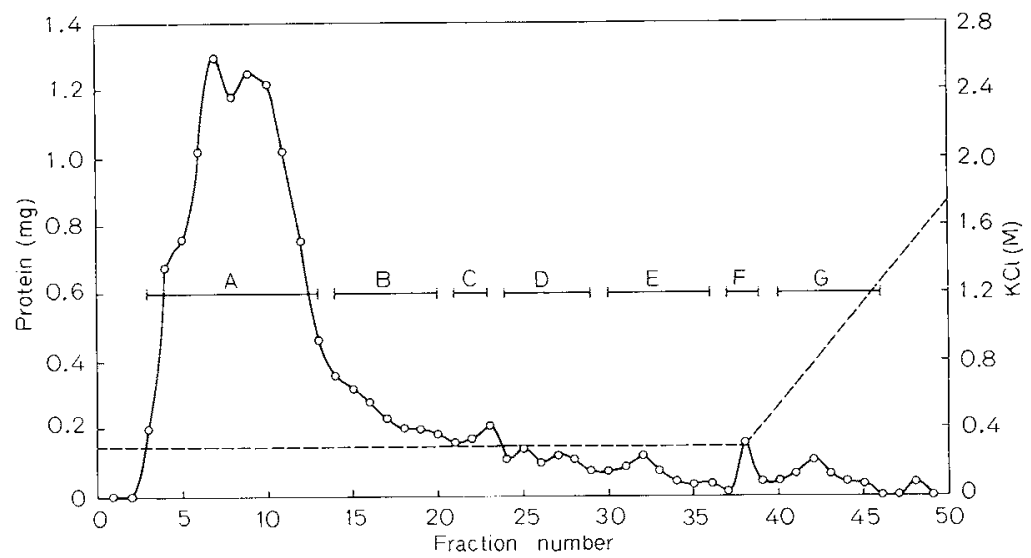

Fig. 10. Affinity chromatography of E. coli $30-S$ ribosomal proteins on $t R N A$-agarose. $14.7 \mathrm{mg} 30-\mathrm{S}$ ribosomal proteins in $18.5 \mathrm{ml}$ binding buffer was chromatographed on a column of tRNA-agarose containing $11.2 \mathrm{mg}$ tRNA; $2.0-\mathrm{ml}$ fractions were collected. These were pooled as indicated for polyacrylamide gel analysis (see Fig. 10). (----) $\mathrm{KCl}$ concentration

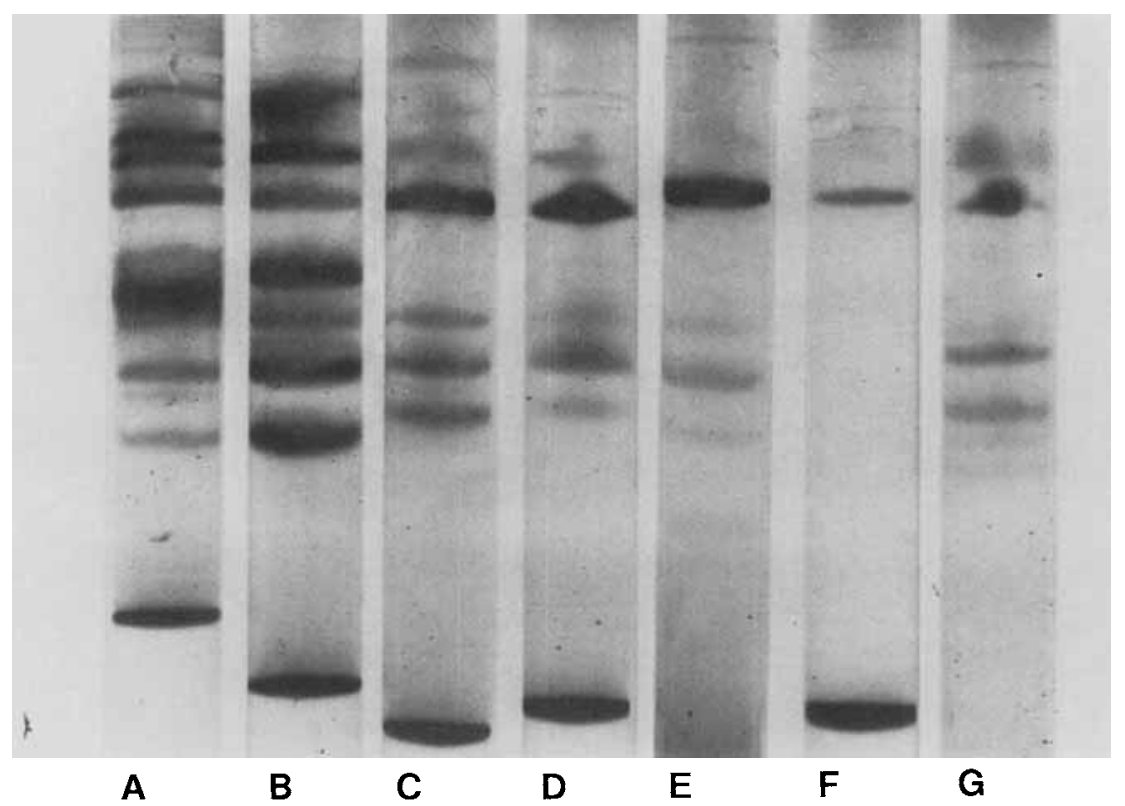

Fig. 11. Polyacrylamide disc gel electrophoresis of 30-S ribosomal proteins chromatographed on $t R N A$-agarose. Protein fractions were pooled as indicated in Fig. 9. The darkly stained band at the bottom of each gel is an artifact of the staining procedure and does not represent a protein component

shown in Fig. 10 and examined by disc gel electrophoresis (Fig. 11). The two pooled fractions, $F$ and $G$, contain the tightly bound proteins eluted by the high-salt/EDTA gradient. Two-dimensional gelelectrophoresis demonstrated that fraction $F$ contained only protein S3. Protein S3 was also the major component in fraction $G$, but small amounts of S6, S9, S13, and S18 were also detected (Fig. 12). These were positively identified by coelectrophoresis with a small amount of total 30-S ribosomal proteins (results not shown).

Pooled fractions C, D and E of Fig. 10 contain 30-S ribosomal proteins retarded by the tRNA matrix during elution with binding buffer. These are proteins that may have a weak affinity either directly for
tRNA or for proteins bound to immobilized tRNA. Comparison of the disc gel electrophoretic mobilities of the proteins in these fractions (Fig. 11) indicates that the major constituent in each is S3. This was confirmed by two-dimensional gel electrophoresis. In addition to $\mathrm{S} 3$ all experiments showed that the trailing region contained S6 and S9 with trace amounts of other proteins, including S4, S5 and S13.

All of the experiments described examined the interaction between ribosomal proteins and RNA in buffers containing $0.3 \mathrm{M} \mathrm{KCl}$ and $0.02 \mathrm{M} \mathrm{Mg}^{2+}$. Only a few experiments using different conditions have been carried out. The patterns of specific protein binding should be modified under conditions which alter the structure of the RNA or proteins. Preliminary 


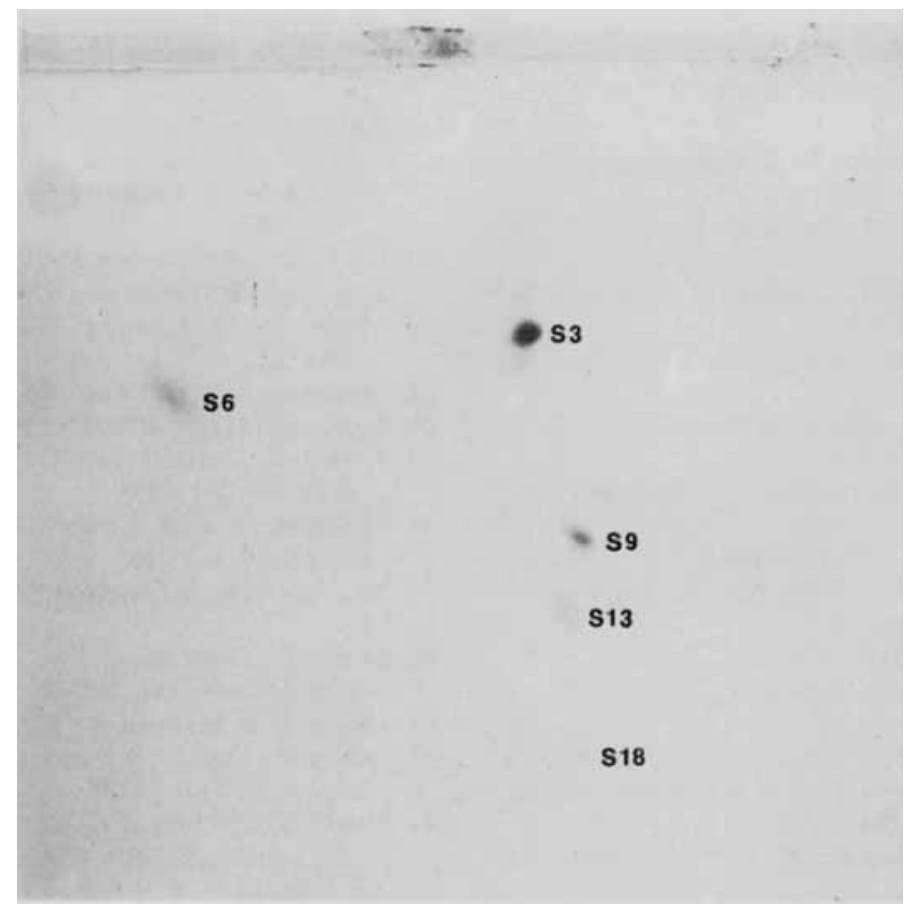

Fig. 12. Two-dimensional gel electrophoresis of the E. coli 30-S ribosomal proteins bound to tRNA-agarose. The ribosomal proteins eluted in fraction G of Fig. 10 were separated by two-dimensional gel electrophoresis as described in Methods and identified as indicated

results using lower-ionic-strength buffers, $0.15 \mathrm{M}$ $\mathrm{KCl}$, indicate a tighter binding of $30-\mathrm{S}$ ribosomal proteins to immobilized tRNA (Burrell and Horowitz, unpublished observations).

The affinity chromatography technique shows that protein S3 and to a lesser degree S6, S9, S13 and S18 bind to tRNA. Recent evidence indicates that all but S6 also bind directly to 16-S RNA when the latter is prepared by an acetic acid/urea method [10]. Numerous investigations have demonstrated that the above proteins and others are important for initiationfactor-dependent binding of fMet-tRNA or EF-Tudependent binding of aminoacyl tRNA to the ribosome (see [27] and [50] for reviews). However, it should be borne in mind that the binding of tRNA in these experiments may be affected indirectly by such factors as the inhibition of mRNA or EF-Tu binding or subunit association. The affinity binding technique provides a method for identifying those ribosomal proteins which interact directly with tRNA. Extension of our studies to experiments with initiator tRNA and other purified tRNA species should permit differentiation between P-site and A-site tRNA binding proteins. Furthermore, regions of the tRNA molecule important for binding to ribosomal proteins could be explored by preparing affinity columns containing immobilized tRNA fragments.

Proteins S3 and to a lesser degree S6, S9, S13 and S18, interact weakly with 5-S RNA (Fig. 6) as well as with tRNA. These proteins may be at or near the proposed site of interaction between tRNA and
5-S RNA on the ribosome [51,52]. Protein L5 also binds to both 5-S RNA and tRNA and could be located near this same ribosomal site.

The affinity binding experiments presented here provide direct evidence for the existence of interactions between certain ribosomal proteins and tRNA, as well as 5-S RNA. These results demonstrate the feasibility of studying ribosomal protein-RNA interactions in E. coli by using RNA immobilized to agarose; a procedure that should be equally applicable to the investigation of such interactions in the structure and function of the eucaryotic ribosome, about which much less is known.

This study was supported in part by USPHS grant, GM 09042. H. R. B. was the recipient of a NSF Predoctoral Traineeship, GZ2695.

\section{REFERENCES}

1. Traub, P. \& Nomura, M. (1968) Proc. Natl Acad. Sci. U.S.A. $59,777-784$

2. Nierhaus, K.\& Dohme, F. (1974) Proc. Natl Acad. Sci. U.S.A. $71,4713-4717$.

3. Horne, J. \& Erdmann, V. A. (1972) Mol. Gen. Genet. 119. $337-344$.

4. Gray, P., Bellemare, G., Monier, R., Garrett, R. A. \& Stoffler, G. (1973) J. Mol. Biol. 77, 133-152.

5. Yu, R.S. T. \& Wittmann, H. G. (1973) Biochim. Biophys. Acta, 324, 375-385.

6. Mizushima, S. \& Nomura, M. (1970) Nature (Lond.) 226, $1214-1218$ 
7. Schaup, H., Green, M. \& Kurland, C. G. (1971) Mol. Gen. Genet. 112, 1-8.

8. Garrett, R. A., Rak, H., Daya, L. \& Stoffler, G. (1971) Mol. Gen. Genet. 114, 112-124.

9. Muto, A., Ehresmann, C., Fellner, P. \& Zimmermann, R. A. (1974) J. Mol. Biol. 86, 411-432.

10. Hochkeppel, H. K., Spicer, E. \& Craven, G. R. (1976) J. Mol. Biol. 101, 155-170.

11. Branlant, C., Krol, A., Srividada, J., Fellner, P. \& Crichton, R. (1973) FEBS Lett. 35, 265-272.

12. Schulte, C., Morrison, C. A. \& Garrett, R. A. (1974) Biochemistry, 13, 1032- 1037 .

13. Garrett, R. A., Muller, S., Spierer, P. \& Zimmermann, R. A. (1974) J. Mol. Biol. 88, 553-557.

14. Spierer, P. \& Zimmermann, R. A. (1976) J. Mol. Biol. 103, $647-653$.

15. Moore, P. (1971) J. Mol. Biol. 60, 169-184.

16. Shimizu, M. \& Craven, G. R. (1976) Eur. J. Biochem. 61, $307-315$.

17. Ginsburg, I. \& Zamir, A. (1976) J. Mol. Biol. 100, 387-398.

18. Lelong, J., Gros, D., Gros, F., Bollen, A., Maschler, R. \& Stoffler, G. (1974) Proc. Natl Acad. Sci. U.S.A. 71, 248-252.

19. Stoffler, G. (1974) in Ribosomes (Nomura, M., Tissieres, A. \& Lengyel, P., eds) pp. 271-308, Cold Spring Harbor Laboratory, Cold Spring Harbor, New York.

20. Noller, H., Chang, C., Thomas, G. \& Aldridge, J. (1971) J. Mol. Biol. 61, 669-679.

21. Czernilofsky, A., Collatz, E., Stoffler, G. \& Kuechler, E. (1974) Proc. Natl Acad. Sci. U.S.A. 71, 230-234.

22. Cantor, C. R., Pellegrini, M. \& Oen, H. (1974) in Ribosomes (Nomura, M., Tissieres, A. \& Lengyel, P., eds) pp. 573-585, Cold Spring Harbor Laboratory, Cold Spring Harbor, New York.

23. Pongs, O., Stoffler, G. \& Lanka, E. (1975) J. Mol. Biol. 99 , $301-315$

24. Fiser, I., Scheit, K. H., Stoffler, G. \& Kuechler, E. (1975) FEBS Lett. 56, 226-229.

25. Cooperman, B. S., Jaynes, E. N., Brunswick, D. J. \& Luddy, M. A. (1975) Proc. Natl Acad. Sci. U.S.A. 72, 2974-2978.

26. Collatz, E., Kuechler, E., Stoffler, G. \& Czernilofsky, A.P. (1976) FEBS Lett. 63, 283-286.

27. Pongs, O., Nierhaus, K. H., Erdmann, V. A. \& Wittmann, H. G. (1974) FEBS Lett. 40 (suppl.), S 28-S 37.
28. Burrell, H. \& Horowitz, J. (1975) FEBS Lett. 49, 306-309.

29. Tissieres, A., Watson, J. D., Schlessinger, D. \& Hollingworth, B. R. (1959) J. Mol, Biol. 1, 221-238.

30. Spitnik-Elson, P. (1965) Biochem. Biophys. Res. Commun. 18, $557-562$.

31. Nomura, M. \& Erdmann, V. A. (1970) Nature (Lond.) 228 , $744-748$.

32. Hills, D. C. \& Horowitz, J. (1966) Biochemistry, 5, 1625-1632.

33. Schleich, T. \& Goldstein, J. (1966) J. Mol. Biol. 15, 136-146.

34. Monier, R. \& Feunteun, J. (1971) Methods Enzymol. 20, $500-507$

35. Marcinka, K. (1972) Anal. Biochem. 50, $304-308$.

36. Scott, J. F. (1968) Methods Enzymol. 12 B, 173-177.

37. Lamed, R., Levin, Y. \& Wilchek, M. (1973) Biochim. Biophys. Acta, 304, $231-235$.

38. Fahnstock, S. R. \& Nomura, M. (1972) Proc. Natl Acad. Sci. U.S.A. $69,363-365$.

39. Robberson, D. \& Davidson, N. (1972) Biochemistry, 11, 533537.

40. Lowry, O., Rosebrough, M., Farr, A. \& Randall, R. (1951) J. Biol. Chem. 193, 265-275.

41. Geiger, P. \& Bessman, S. (1972) Anal. Biochem. 49, 467-473.

42. Leboy, P., Cox, E. \& Flaks, J. (1964) Proc. Natl Acad. Sci. U.S.A. 52, 1367-1374.

43. Hardy, S. J., Kurland, C. G., Voynow, P. \& Mora, G. (1969) Biochemistry, 8, 2897-2905.

44. Kaltschmidt, E. \& Wittman, H. G. (1970) Anal. Biochem. 36, $401-412$.

45. Howard, G. A. \& Traut, R. R. (1973) FEBS Lett. 29, $177-180$.

46. Fishbein, W. N. (1972) Anal. Biochem. 46, 388-401.

47. Garrett, R. A., Schulte, C., Stoffler, G., Gray, P. \& Monier, R. (1974) FEBS Lett. 49, 1 -4.

48. Aubert, M., Scott, J. F., Reynier, M. \& Monier, R. (1968) Proc. Natl Acad. Sci. U.S.A. 6l, $292-299$.

49. Aubert, M., Bellemare, G. \& Monier, R. (1973) Biochimie (Paris) 55, 135-142.

50. Brimacombe, R., Nierhaus, K. H., Garrett, R. A. \& Wittman, H. G. (1976) Prog. Nucleic Acid Res. Mol. Biol. 18, 1-44.

51. Erdmann, V. A., Sprinzl, M. \& Pongs, O. (1973) Biochem. Biophys. Res. Commun. 54, $942-948$.

52. Horne, J. \& Erdmann, V. A. (1973) Proc. Natl Acad. Sci. U.S.A. $70,2870-2873$.

H. R. Burrell, Neuroscience Laboratory, University of Michigan, 1103 East Huron, Ann Arbor, Michigan, U.S.A. 48109

J. Horowitz*, Department of Biochemistry and Biophysics, Iowa State University of Science and Technology,

Ames, Iowa, U.S.A. 50011

* To whom correspondence should be addressed. 